\title{
ВРЕМЕНА И ДЛИТЕЛЬНОСТИ ФОРМИРОВАНИЯ УГЛЕВОДОРОДНЫХ МЕСТОРОЖДЕНИЙ, - ПО ДАННЫМ ИЗОТОПИИ БЛАГОРОДНЫХ ГАЗОВ
}

\section{Толстихин И.Н.}

Геологический институт КНЦ РАН, Апатить

Атмосфера является единственным источником изотопов ${ }^{20} \mathrm{Ne},{ }^{36} \mathrm{Ar},{ }^{84} \mathrm{Kr},{ }^{130} \mathrm{Xe}$ в земной коре: эти изотопы не возникают в недрах Земли; они растворяются в метеорных водах и переносятся в недра после погружения вод. Концентрации БГ в метеорных (впоследствии подземных) водах известны из данных о растворимости. Знание исходных концентраций (и отношений) БГ позволяет моделировать их фракционирование между сосуществующими газовыми, нефтяными и водными фазами в процессе образования, миграции и хранения углеводородов.

Радиогенные (*) изотопы, ${ }^{4} \mathrm{He}^{*},{ }^{21} \mathrm{Ne}^{*},{ }^{40} \mathrm{Ar} *,{ }^{136} \mathrm{Xe}$, мигрируют из пород (минералов), в которых они возникают в результате радиоактивного распада, деления ядер и ядерных реакций в подземные воды, смешиваются с атмогенными изотопами и, с течением времени, накапливаются в системе вода - порода. Накопление радиогенных изотопов в поровых водах проявляется в росте отношений ${ }^{4} \mathrm{He}^{* / 20} \mathrm{Ne}_{\mathrm{ATM}},{ }^{21} \mathrm{Ne}^{*} / 20 \mathrm{Ne}_{\mathrm{ATM}},{ }^{4} \mathrm{He}^{* / 36} \mathrm{Ar}_{\mathrm{ATM}},{ }^{40} \mathrm{Ar}^{*} /{ }^{36} \mathrm{Ar}_{\mathrm{ATM}}{ }^{136} \mathrm{Xe}^{130} \mathrm{Xe}_{\text {Атм}}$. Концентрации родительских изотопов ${ }^{238} \mathrm{U},{ }^{235} \mathrm{U},{ }^{232} \mathrm{Th},{ }^{40} \mathrm{~K}$ в содержащих подземную воду породах, известные из измерений или a priori данных, позволяют ответить на вопрос как долго накапливались радиогенные изотопы. Поскольку растворимости благородных газов в воде весьма низки, БГ практически полностью переходят в углеводородные фазы; поэтому отношения изотопов БГ не меняются при дегазации вод в ходе формирования месторождений углеводородов:

Концентрации радиогенных изотопов БГ в пористом пространстве месторождений углеводородов, как правило, настолько высоки, что их невозможно генерировать и накопить in situ. Единственным источником радиогенных изотопов БГ в месторождениях углеводородов являются подземные воды, в которые эти изотопы мигрируют из вмещающих воду пород и накапливаются в ней. Таким образом, отношения ${ }^{4} \mathrm{He}^{* / 20} \mathrm{Ne}_{\text {Aтм}},{ }^{21} \mathrm{Ne}^{* / 20} \mathrm{Ne}_{\text {Атм }},{ }^{4} \mathrm{He}^{* / 36} \mathrm{Ar}_{\text {Aтм }},{ }^{40} \mathrm{Ar}^{*} / 36 \mathrm{Ar}_{\text {Атм }}$ в углеводородных месторождениях пропорциональны интервалу между временем погружения подземных вод (прекращением их контакта с атмосферным воздухом и началом накопления в них радиогенных изотопов) и дегазацией вод в ходе формирования месторождений углеводородов: «интервал погружение - дегазация, ИПД».

Использование мирового банка данных позволяет определить значения ИПД для большого количества месторождений углеводородов, расположенных в разных тектонических обстановках: на древних платформах, на молодых платформах, в мобильных поясах. ИПД систематически увеличиваются с возрастом осадочных - пород источников углеводородов, и значения ИПД близки к этим возрастам. Эта важная особенность ИПД для различных месторождений углеводородов свидетельствует о: (а) происхождении радиогенных изотопов БГ в подземных водах, при дегазации которых возникло месторождение; (б) относительно недавнем времени образования месторождений углеводородов, - иначе они не могли бы захватить БГ из древней воды; (в) коротких интервалов времени образования месторождений.

При достаточно детальных исследованиях время и продолжительность образования углеводородных месторождений могут быть оценены. Например, почти постоянные отношения ${ }^{21} \mathrm{Ne}^{*} / 20 \mathrm{Ne}_{\text {Атм }},{ }^{40} \mathrm{Ar}^{*} / 36 \mathrm{Ar}_{\text {Атм}}$, измеренные в образцах из нефтяного месторождения Магнус (Северное море), соответствуют длительности накопления $\approx 10$ млн. лет. Следует подчеркнуть, что вышеупомянутые соотношения изотопов БГ дают оценки времени, которые не зависят от геологических реконструкций.

Количества БГ в углеводородных месторождениях позволяют характеризовать объем подземных вод, из которого БГ были перенесены в месторождение; обычно этот объем превышает объем месторождения на порядки величины. 